\title{
PROPOSING A MODEL FOR ENTREPRENEURSHIP DEVELOPMENT: THE ROLE OF ENTREPRENEURS' CASH WAQF INTENTION
}

\author{
Sherifah Oshioke Musa ${ }^{1}$ \\ Marhanum Che Mohd Salleh ${ }^{2}$
}

\begin{abstract}
The purpose of this paper is to propose a model of entrepreneurship development by focusing on the role of cash waqf intention as a mediator on the relationship of cash waaf awareness, religiosity, attitude towards act, subjective norms, perceived behavioural and entrepreneurship development. By enhancing the theory of planned behaviour, a structured question was designed to survey 459 Nigerian entrepreneurs. SEM analysis was used to test the theoretical framework and to propose a model of entrepreneurship development in Nigeria by means of Waqf. Result shows that the most important variables to explain entrepreneurs' cash waqf intention for business growth are cash waqf awareness and attitude towards cash waqf. It is argued in this research that the presence of high-level of cash waqf awareness and the attitude towards cash waqf can play an important role in achieving business growth. The paper extends the applicability of the theory of planned behaviour, cash waqf awareness and religiosity in investigating the effect of cash waqf intention for business development.
\end{abstract}

Keywords: Awareness, Religiosity, Waqf

JEL Classification: A13, D91, G41, L31

Received : September 5, 2017

Revised : August 2, 2018

Accepted : August 7, 2018

1. Department of business administration, Kulliyah of Economics and Management Science, International Islamic University Malaysia sherifahmusa@gmail.com.

2. Department of Finance International Islamic University, Malaysia marhanum@iium. edu.my. 


\section{INTRODUCTION}

Entrepreneurs are important individual whose work preferences are based on self-reliance and self-direction (Baruch, 2004; Gibb, 2002a, b; Hall, 2002). The changes in the political and socio-economic environment have resulted in fewer opportunities for continuous organizational employment, hence an increase in the number of entrepreneurs. Entrepreneurs could be a micro, small, medium or a large-scale business owner. On the macro-level, econometric research shows that new and small businesses did not just contribute significantly to job creation, but also in innovation and economic growth. Interestingly, Micro, Small and Medium businesses has heightened self-employability to economically distressed areas, handicaps, and those who have never be qualified to be employed (Taylor, 2007; Schumpeter, 1934).

However, evidences show that entrepreneurs have challenges funding their businesses. Financing institutions such as banks, amongst all other reasons the banks consider micro enterprises as risky businesses that lack collateral, that do not have sufficient documents to support their loan application and have no financial track records (Nurbani, Yeow, Noor Ashikin, \& Chin, 2011). In addition, the micro entrepreneurs suffer this most. They are also scared to patronize bank loans because of the strict requirements and high interest payback which they cannot provide.

In this regard, a possible means of financing that is, non interest based is Islamic financing (Wardiwiyono, 2012). Islamic financing is another alternative to manage socio economic situations in a country. It is understood in the context of Islamic attitude towards ethics, wealth distribution, social and economic justice. The system is based on the goals, principles and values of the Sharia law. Islamic codes underlying the Islamic financial system are supported by various verses of the Quran. Such as in the prohibition of riba (Quran 2:278-279), encouraging risk sharing (Quran 2:275), protection of individual property rights, carrying out lawful trade (Quran 2:275), zakat and the establishment of waqf (Quran 21:73). Among all other Islamic social finance platforms, Waqf has recently become an Islamic financial tool for socioeconomic development. Waqf, is an Islamic voluntary sector. It is the appropriation of any property from private ownership and the dedication of its usufruct to charitable purposes. Its significance arises out of its centrality to the Islamic principle of charity (zakat). Waqf practices are supported by the following verse;

"Indeed, the men who practice charity and the women who practice charity and [they who] have loaned Allah a goodly loan - it will be multiplied for them, and they will have a noble reward", (Quran 57:18).

This verse depicts that by spending in charity, the wealth does not decrease rather it increases (Sahih al-Bukhari vol.9, Book 93, Hadith 587). In other words, whatever cost that is pushed unto the society comes back as greater benefits. Islam made us understand in ethics that those who possess the money are not the owners of the wealth; they are only trustees, so they are expected to spend it in good cause. This principle has continued to guide the Muslims to ensure the equitable distribution of wealth. The rudimentary in executing these social economic activities such as payment of Zakat, and the establishment of waqf, has supported the social, economic and cultural development of the Muslim societies 
and countries. Cash waqf an aspect of waqf is amply appreciated by the Muslims because it can be used to address the old and persistent issues of lack of finance for micro entrepreneurs, for them to attain a better stage than their present situation. Given the increasing importance of entrepreneurship in contemporary careers, this study aims to uncover the determinants of entrepreneurial intentions on cash waqf for their business growth. The paper study samples of entrepreneurs of small and medium business owners in Nigeria.

In Nigeria the use of cash waqf for business activities is not known specifically in Edo state Nigeria. Hence, the possibility of its implementation as an alternative source of financing for the micro entrepreneurs in Edo state Nigeria is centered on the perception about it by the micro, small and medium (MSMEs) entrepreneurs in the state. Though cash waqf operation for socio economic development has been successful in other parts of the world but the situation might be different in a non-Muslim dominated state and where cash waqf has never existed. However, evidence show that non-Muslims patronizes and uses sharia Islamic products and services for their attractive benefits of non interest payment (Khalid, n.d.). Like other Islamic non interest financial products, waqf model has advantages over conventional micro finance. This can act as a unique selling point in attracting non-Muslims ethical investors.

In view of this, the theory of planned behavior (TPB) shows that human performance is influenced by three kinds of considerations: beliefs about the likely consequences of the behavior (behavioral beliefs), beliefs about the normative expectations of others (normative beliefs), and beliefs about the presence of factors that may facilitate or impede performance of the behavior (control beliefs). Given a sufficient degree of actual control over the behavior, people are expected to carry out their intentions when the opportunity arises. Intention is thus assumed to be the immediate antecedent of behavior. On this note, the intention of the study group towards cash waqf usage for their business growth can be positively or negatively influenced by cash waqf awareness, religiosity, attitude toward the act, subjective norm, and perception of behavioral control (Icek Ajzen, 1991).

This study focuses on the perception of cash waqf, in an effort to proffer it as an alternative source of financial support to micro, small and medium entrepreneurs. Objectively, the research aims to examine the intentions of micro entrepreneurs on cash waqf for perceived business development. That is explore the relationship between cash waqf awareness, religiosity, attitude towards cash waqf, subjective norms, perceived behavioral control for perceived business development, investigate the mediating effect of cash waqf intention for business development.

\section{LITERATURE REVIEW}

The understanding of entrepreneurship owes much to work of economist such as Joseph Schumpeter in the 1930s, and another economist such as Von Mises (1949). They came up with lot of on entrepreneurship which are today still in use. Recent researchers Valliere (2013) contributed by using cognitive psychology to observe the basis for entrepreneurial awareness and connected it to theories of attention in strategic management and decision making. That is the awareness of business opportunities and strategies for a successful business operation. This was 
to provide a theoretical basis or model for how entrepreneur need to pay attention to new opportunities. However, the work of Valerie had not specific factor which an entrepreneur needs to be aware of.

In Jiao et al. ( 2014), they viewed that the act of Entrepreneurship is mostly dependent on the qualities of the entrepreneur. That entrepreneurs needs to possess some qualities to be business alert, to be foremost in identifying business and profit opportunities, acquisition of knowledge, innovative, hardworking, risk taker, optimistic and self-confident. However, their research did not address the challenges of lack of finance. In a different way, other researchers viewed entrepreneurship growth in relationship to provision and the availability of finance. In view of this, Whited (2006) opined that finance was an external constraint which firms face without stating better measures of financing the entrepreneurs. With no proper measures for funding business, its growth is hindered. This is a common phenomenon in most countries. This shows why government in some countries sometimes support them in funding or carry out other measures to assist in businesses (Tohirin, 2010c).

In different opinions researchers emphasized on the need for funds for entrepreneurs in their business start off, sustainability and growth. In this regards, Nurbani et al. (2011) were of the view that many micro and small enterprises still require additional working capital and financing facilities to support and modernize their operations. In this regards, researchers such as Foss et al. (2009) went forward to province possible way entrepreneurs can get funds for their businesses and types of funding for small businesses to start their operation. It explained that some business start-ups are funded either with equity finance or credit-card debt. It also emphasizes that businesses can solicit for donations. In the research of Lee et al. ( 2002) he also proposed the use of bank credit such as the use of credit cards as means for financing. Ordanini et al. (2011) proposed crowd funding, which they said should be a collective effort by consumers who pool their money together in other to invest or support efforts initiated by other people or organizations. Other measure of financing business proposed is trade credit (Petersen et al., 1997). In support of this Lee et al. (2011) also suggested the use of trade credit as measure to finance businesses. Other way of financing is through the government. Rai (2007) amongst others proposed government credit programs and co-financing. However, credit financing is associated with interest rate payment (Shinsuke 2014). In view of this (Golbeck \& Linetsky, 2013; Yang, 2011) opined most of the credit financing proposed by some of the stated researchers was not the best alternative means of funding for entrepreneurs. Entrepreneurs who opted for such measures of financing were face with problems of high interest rate and inability to pay back their loans. As a result, entrepreneurs are sometimes discouraged from doing businesses due to lack of funding and high interest rate.

Also, many businesses are not started or even ended due to these. However, presently researchers such as Wardiwiyono, (2012) viewed that alternative source of financing or funding entrepreneurs that will yield greater success than the conventional measures is Islamic financing. In support of this Islamic finance researchers such as Ayub, (2007) and Ismail et al., (2010) both proposes Islamic finance as a better alternative to the conventional measures which was not very effective. Hanif \& Iqbal, (2010) conducted a study to evaluate the suitability 
of existing business environment in Pakistan for application of Sharia based financing; findings show sharia based financing was suitable for business. Osman and Ali (2008) on their opinion encouraged entrepreneurs to obtain their financing from Islamic banks whose operations are based on Shari'ah, which differs in its spirit and motivation. In view of this, Masyita et al. ( 2005), Hasan et al.(2008), Ibrahim et al. (2013) and Shahimi et al. (2013) went further to specify and propose waqf as a better alternative for financing socio economic activities. However for Islamic method of financing to be utilized and successful, there is need to examine the attitude towards Islamic finance (Jaffar \& Musa, 2014). Figure 1 shows this research theoretical framework.

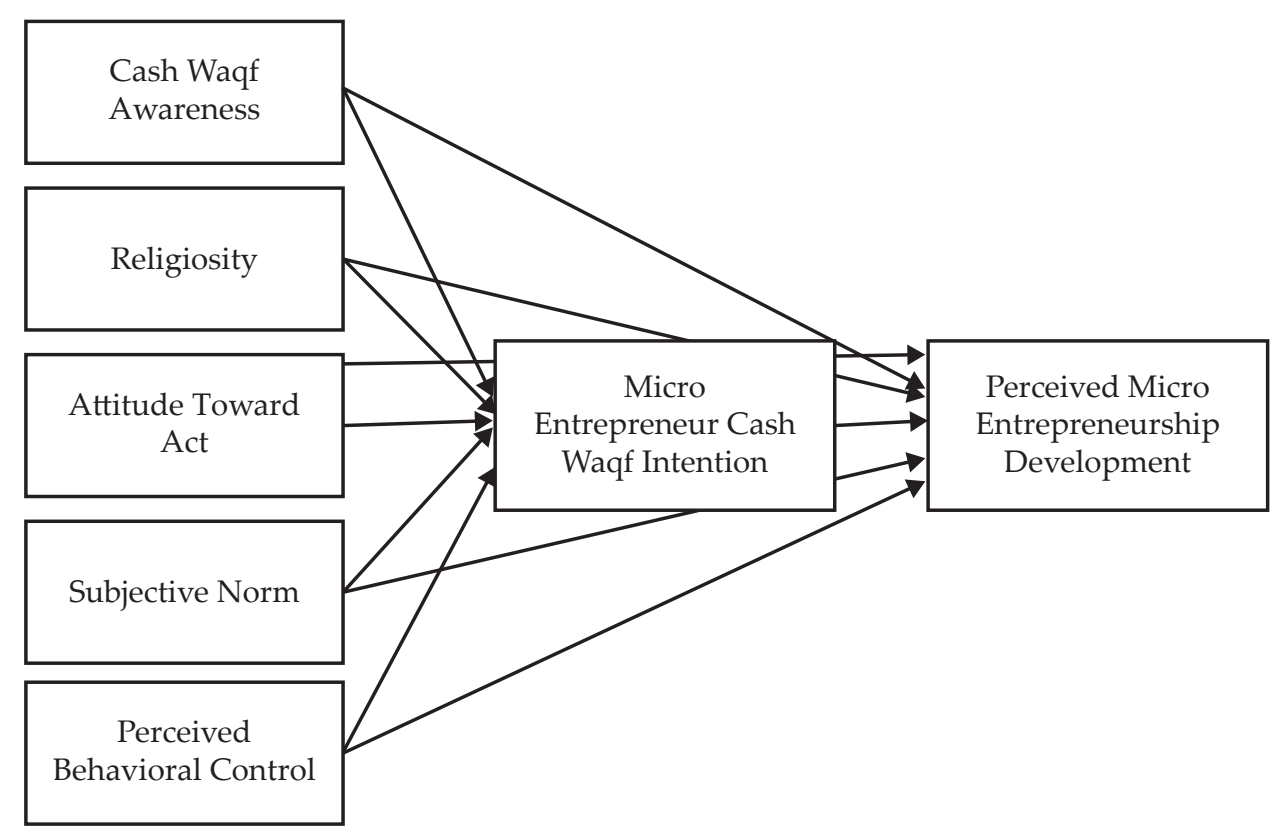

Figure 1.

Research theoretical frame work

\subsection{Hypotheses Development}

This section is to identify and formulate a formal statement that present the expected relationship between the independent and dependent variable of this research, Hair et al., (2006). The research hypothesis is developed based on the theory of planned behavior. Cash waqf awareness and religiosity are external variable which is introduced into the TPB variables in this research work. A number of recent studies have introduced external variables that dilute the Theory of Planned Behavior. Depending on the study, these external variables may or may not increase the attitude or behavior correlation (Knabe, 2012). 


\subsubsection{Entrepreneurs Cash Waqf Awareness}

Firstly, Entrepreneurship development is associated with the level of awareness in the country (Provan et al., 2012; Endley, 1995) . In this regard, entrepreneurship alertness is also considered as entrepreneurship awareness. However, there are factors which influence this alertness among entrepreneurs. Based on this, Tang (2009) opined that there is the problem of people not recognizing or noticing business opportunity. This could be influenced differently by the surrounding at which they exist. In view of this, Acs (2010) opined that the lack of education, awareness and huge capital, have motivated many of the micro entrepreneurs into been a small business owner and hindered their business growth. In this regards, Provan et al. (2012), viewed awareness is synonymous with usage. On a different note, Ismail Abdel Mohsin (2013) proved that the with great awareness on Islamic finance, countries like chad, UK and Singapore have waqf scheme for social economic development such as financing of medical care, teachers and sponsoring orphans. He also proved, the non-Muslim dominating country such as Singapore and UK are aware of cash waqf and they practice it. Also, countries such as Malaysia, Jordan, Somalia, and Chad are known to have great awareness and acceptability of waqf. Also, Provan et al., (2012) examined the awareness of evidence based practices by the public organizations that fund services in the North American. They found that awareness and evidence-based practices was strongly connected. Endsley (1995) also proved the relationship between practices and awareness in his model. In his research he presented a theoretical model of situation awareness based on its role in dynamic human decision making in a variety of domains. Situation awareness was presented as a major concern in system operation, based on a descriptive view of decision making.

\section{$H_{1}$ : Cash waqf intention will significantly mediate the effect of cash waqf awareness towards perceived business growth}

\subsubsection{Entrepreneur and Religion}

This is to examine the influence of religion belief on micro entrepreneurs' intentions in the use of cash waqf to enhance their business growth. Stanford \& Brewer (2011) viewed the magnitude of religious influence varies in people, this means the degree of being religious reflects differently in people's attitude and behavior. Hence, there is possibility that there is religious effect on entrepreneurs' decision making. Therefore, it is logical to deduce that the greater intensity of one's religious affiliation, the higher will be chances that he will strives to conform to his cash waqf intentions.

$\boldsymbol{H}_{2:}$ Cash waqf intention will significantly mediate the effect of religiosity for perceived business growth

\subsubsection{Entrepreneurs and the Theory of Planned Behavior}

The theory of planned behavior (TPB) was developed by Icek Ajzen in 1985. In this regards, Adewale, Yusuf, Ghani, Meera, \& Manap (2012) viewed the theory 
of planned behavior proposes a model which can measure how human actions are guided and it also predicts the occurrence of a particular intentional behavior. Past studies reflect successful applications of the theory, and this has reinforce its utility for researching intentions predictions of micro, small and medium enterprise entrepreneurs and a new focus on intention on cash waqf for business development (Knabe, 2012). In view of this, the theory of planned behavior (TPB) will show how the entrepreneurs will be influenced by three kinds of considerations: beliefs about the likely consequences of the behavior (behavioral beliefs), beliefs about the normative expectations of others (normative beliefs), and beliefs about the presence of factors that may facilitate or impede performance of the behavior (control beliefs). Given a sufficient degree of actual control over the behavior, people are expected to carry out their intentions when the opportunity arises. On this note, the intention of the study group towards cash waqf usage for their businesses can positively affect cash waqf awareness, attitude toward the act, subjective norm, and perception of behavioral control to achieve growth and development (Icek Ajzen, 1991). Hence this research proposes the following five hypotheses;

$\mathrm{H}_{3}$ : Cash waqf intention will significantly mediate the effect of attitude towards the act, for perceived business growth

$\boldsymbol{H}_{4}$ : Cash waqf intention will significantly mediate the effect of subjective norms towards perceived business growth

$\boldsymbol{H}_{5}$ : Cash waqf intention will significantly mediate the effect of behavioral control towards perceived business growth

\subsubsection{Entrepreneurs Cash Waqf Intention (Mediator)}

This is the micro entrepreneur intention towards cash waqf. Farkas \& Gubik, (2013) opined intention is thus assumed to be the immediate antecedent of behavior. While Malebana (2014), offers a critical insights to the understanding of the underlying process of behavioral intentions. A particular note on intentions is that the underlying attitudes are perception based. In physiological study, the presence of intentions had been proven to be predictor of planned behavior. This is true when the behavior to be observed is rare, hard to observe or that it involves an unpredictable long period of time lapse. The use of cash waqf for financing business by entrepreneurs is a process that involves considerable planning, considering other possible influential factors over time (Kautonen et al., 2013). Just as intentions predicts behavior certain attitudes predicts intention. In view of this study, entrepreneurial intentions as a mediator is influenced by cash waqf awareness, attitude towards act, subjective norms and perceived behavioral control. The entrepreneurial intentions determines the use of cash waqf to achieve business growth and development (Ibrahim, Amir, et al., 2013)

\subsubsection{Perceived Business Development (Dependent Variable)}

In this research perceived business development is considered as a dependent variable that could be directly and indirectly affected by cash waqf awareness, 
religiosity, attitude towards cash waqf, subjective norms, perceived behavioral control. The act of entrepreneurship is perceived successful if the entrepreneurs have the required provisions and able to achieve their business objectives. Amongst other objectives, micro entrepreneurs prioritize their business survival, generating income for growth. The ability to achieve entrepreneurship development could be affected directly or indirectly by some factors. Lack of Finances to maximize their potentials is one of such challenges faced by entrepreneurs (Kerr \& Nanda, 2011). Hence there is need to know if entrepreneurs cash waqf intentions effect their perceived business growth (Tohirin, 2010c).

\section{METHODOLOGY}

\subsection{Data}

A total number of 500 questionnaires were distributed and also returned given a response rate of 100 percent. However, after vetting 459 questionnaires (92 percent response rate) were used for analysis. The questionnaires removed were the ones marked with more than one answers and the ones which only had the demographic section answered.

The 459 data used meet the required number for a SEM analysis Hair et al., (2006). In the data analysis, analysis of moment structure (Amos) was used. This is because Amos gives the power to easily perform Structural Equation Modelling (SEM), (Mueller et al., 2008; Pallant, 2013). The use of SEM, was relevant in the creating of models to test hypotheses, accommodates multiple latent constructs and confirms relationships among observed and latent variables, moving beyond regression to gain additional insight. The SEM application involved two stages. The first stage was exploratory factor analysis (EFA) and the second stage was confirmatory factor analysis (CFA).

\subsection{Estimation Technique}

The technique used is quantitative methods, which involves quantitative data collection and analysis. This is the systematic empirical investigation of observable phenomena via statistical or mathematical techniques (Hair et al., 2006). The quantitative empirical investigation is based on the use of seven constructs and five hypotheses.

The measurement items are based on seven construct which are cash waqf awareness, religiosity, attitude towards cash waqf, subjective norms, perceived behaviour, cash waqf intentions and perceived entrepreneurship development. Cash waqf awareness is measured based on the familiarity and usage of cash waqf for funding business activities (Durso \& Sethumadhavan, 2008). Religiosity is measured on belief (El- menouar 2014) while attitude towards act items is on the aspect of behavioral belief which produces a favourable or unfavourable attitude toward the behaviour at a particular time and context. Subjective norms are measured base on normative beliefs which result in perceived social pressure from family, friends and colleagues (Ajzen, 2013). The control beliefs give rise to perceived behavioral control. In combination, cash waqf awareness, religiosity, attitude toward the behavior, subjective norm, and perception of behavioral control 
lead to the formation of a behavioral intention of cash waqf for entrepreneurship development. Cash waqf intentions were measured based on entrepreneurs' cash waqf purpose, plans and aims. Perceived business development was measured on financial needs and achieving business objectives (Parvin, Rahman, \& Jia, 2012; Nafukho \& Muyia, 2010).

\subsection{Empirical model}

The study population are small and medium enterprise owners; they engage in small business activities for a sustainable livelihood in Edo state Nigeria. This group of persons are among the poorest in the state and majority of them are mostly face with the problem of finances to sustain their businesses. Relevant information can be prompted from this group on this research related matters.

\section{RESULT AND FINDING}

Overall three stages of statistical is done for the quantitative analysis which started with preliminary data analysis, follow by exploratory factor analysis (EFA) and confirmatory factor analysis (CFA).

\subsection{Reliability Analysis}

Reliability was done to confirm the consistency of the construct items. Cronbanch alpha values range between 0 and 1.0, higher value indicates higher reliability among the indicators (Hair 2010). The scale is used to confirm the reliability of all measurements items for each of the seven constructs. According to Pallant (2011), a conbranch alpha value of 89 suggests very good internal consistency reliability for the scale. In this research, the Cronbach alpha is 0.9 when $p>0.6$. This suggests very good internal consistency the data items are related, suitable, and reliable. The Cronbach alpha reliability test for each of the construct is well above 0.7 which is considered that the constructs have been correctly scored. The result is Cashwaqf awareness (0.89), religiosity (0.859), attitude towards the cash waqf (0.839), subjective norms (0.798), perceived behavioural control (0.740), cash waqf intention (0.917) and perceived business development (0.921) has the highest Cronbach alpha. The result indicates that none of the construct or items measures something different from the scale as a whole.

\subsection{Exploratory factor analysis}

Result showed that measure of sampling adequacy Kaiser-Meyer Oiken (KMO) is 0.895 exceeding the recommended value of 0.6 (Pallant, 2013). Hence it is appropriate for factor analysis using principle component analysis (PCA) method. The Bartlett's Test of spherity also reached statistical significance (0.000), supporting the factorability of the correlation matrix. With the use of varimax rotation, seven factors were extracted with eigenvalue greater than 1 (11.057, 3.981, 3.163, 2.252, $1.805,1.691,1.368)$ explaining 66.6 percent of total variance. Respectively all seven factors were named, cash waqf awareness (AWARE), religiosity (REL), attitude 
towards the act (ATTD), subjective norms (SUBNORM), perceived behavioural control (PBC), cash waqf intention (CWIN) and perceived business growth (PMBD). In communality, the higher value represents higher correlation among the constructs respectively. The result of communality points out SUBNORM 2, SUBNORM 3 and PCB 5 had the highest communality.

The highest factor is perceived behavioural control (PBC) it has the highest eigenvalue and variance (eigenvalue $=2.1$ variance $=72$ percent) it indicates as the most important factor perceived by the respondents for perceived entrepreneurship development. Cash waqf intention is next, (eigenvalue $=3.5$ variance $=70.5$ percent). This is followed by attitude towards an act (eigenvalue $=3.7$ variance $=68$ percent), perceived business growth (eigenvalue $=4.7$ variance $=67.8$ percent). Subjective norms (eigenvalue $=2.6$ variance $=65$ percent) cash waqf awareness, (eigenvalue $=$ 3.8 variance $=64$ percent ) and the last is religiosity (eigenvalue $=3.8$ variance $=$ 54 percent). Overall results of factor analysis show seven underlying constructs considered to be relevant to measure Perceived MSME's development.

\subsection{Confirmatory Factor Analysis (CFA)}

Prior to the conduct of CFA, all necessary EFA has been done. CFA is the third stage of quantitative analysis. It is to test and confirm specific hypotheses, theories concerning the structure underlying a set of variables (Kline, 2011; Hair et al., 2010) This measurement model is confirmed by fit statistics such as root mean square error of approximation (RMSEA), degree of freedom (df), Chi-square $\left(X^{2}\right)$, normed fit index (NFI), comparative fit index (CFI), Tucker-Lewis index (TLI), and incremental fit index (IFI).

The measurement model is the first order confirmatory factor analysis (CFA) carried out to test the relationship between the independent constructs. The first step was the examination of the loadings, particularly focusing on any non-significant loading. Not all the measurement items in the constructs were statistically significant. Some of the items had low loadings ranging from 0.3 to 0.4 not meeting the requirement of loading, values of 0.7 (Hair et.al. 2010). The 4 items with low loadings in the constructs were PBC1, PBC2, PBC3, and SUBNORM 4, they were deleted, and the model was re-estimated. In the re-estimation the model achieved the majority of the fit indices including $X^{2}=1673.449$, and a $\mathrm{p}$ value $=$ 0.000 . The Bentler comparative fit index $(\mathrm{CFI})=0.906$ is higher than the acceptable fit of $\geq 0.95$. The root mean square error of approximation (RMSEA) $=0.059$ is below threshold of 0.05., $\mathrm{df}=639$, incremental fit index $(\mathrm{IFI})=0.909$ higher than acceptable fit and approximately the Lewis Index (TLI) $=0.9$, (Kline, 2011; Hair et al., 2010; Hu \& Bentler, 1999). Also, the root mean square residual (RMR) $=0.05$ below threshold of $<0.08$. 


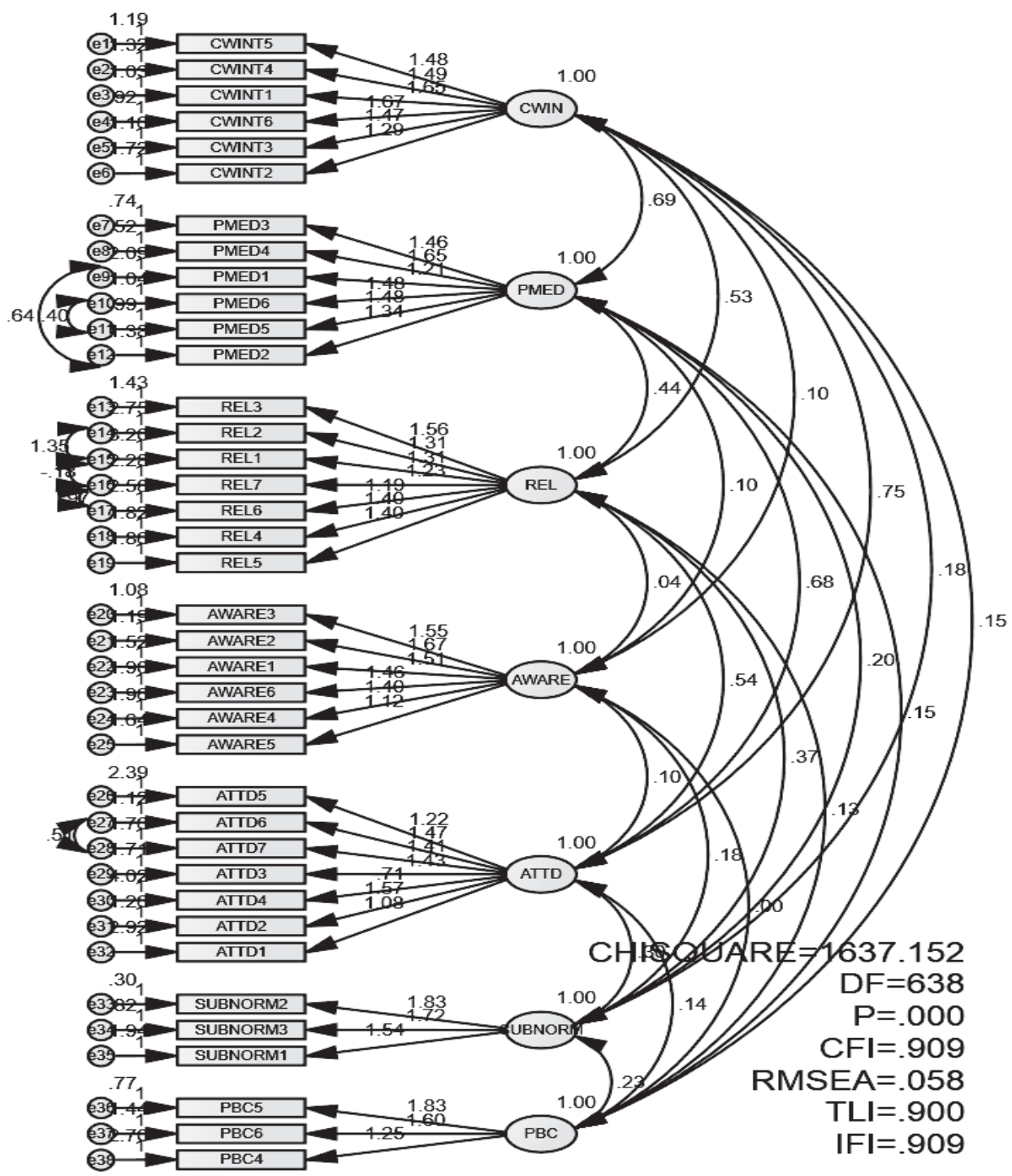

Figure 2

SEM measurement model for constructs

\subsubsection{Reliability and Validity TEST}

The reliability of the constructs is confirmed in the measurement model using the construct reliability (CR) and average variance extracted (AVE). A high value of $C R$ and AVE indicates there is internal consistency all measures are reliably representing their constructs (Hair 2010). The standardized solution of each factor loading and their corresponding error variance is presented in table 1 . The variables specified to measure an underlying construct were found to be mostly reasonably and statistically significant. Most of the factors fulfilled the requirement for convergent validity 0.50 and above and not exceeded 1.00 . The variance 
of the error terms was found to be in the range of requirement for statistical significance. The measurement error represents other variation for a particular observed variable and the variance of a measurement error is estimated. Based on the squared multiple correlation result, SUBNORM 3 explained highest 78.4 percent of the variance is accounted for by subjective norm. Followed by CWINT6, which is explains 75.2 percent of the variance accounted for by cash waqf intention. The third is PMBD 3, it accounts for 74 percent of the variance accounted for by perceived micro business development. In whole the result that loadings were statistically significant.

Table 1.

Reliability and Validity of the constructs

\begin{tabular}{|c|c|c|c|c|c|}
\hline Constructs & Items & $\begin{array}{c}\text { Standardized } \\
\text { regression } \\
\text { Weight }\end{array}$ & $\begin{array}{l}\text { Standard } \\
\text { error } \\
\text { (S.E) }\end{array}$ & $\begin{array}{c}\text { Critical } \\
\text { ratio } \\
\text { (C.R) }\end{array}$ & $\begin{array}{c}\text { Squared } \\
\text { multiple } \\
\text { correlation } \\
\text { (SMC) }\end{array}$ \\
\hline \multirow[t]{6}{*}{ Cashwaqf intention } & CWINT5 & .805 & .072 & 20.465 & .648 \\
\hline & CWINT4 & .792 & .075 & 19.951 & .627 \\
\hline & CWINT1 & .853 & .074 & 22.367 & .727 \\
\hline & CWINT6 & .867 & .072 & 22.988 & .752 \\
\hline & CWINT3 & .806 & .072 & 20.492 & .649 \\
\hline & CWINT2 & .702 & .077 & 16.835 & .493 \\
\hline \multirow{6}{*}{$\begin{array}{l}\text { Perceived } \\
\text { micro business } \\
\text { development }\end{array}$} & PMBD3 & .861 & .064 & 22.689 & .741 \\
\hline & PMBD4 & .917 & .065 & 25.176 & .567 \\
\hline & PMBD1 & .642 & .081 & 14.939 & .412 \\
\hline & PMBD6 & .823 & .070 & 21.102 & .677 \\
\hline & PMBD5 & .830 & .069 & 21.392 & .689 \\
\hline & PMBD2 & .753 & .072 & 18.550 & .567 \\
\hline \multirow[t]{7}{*}{ Religiosity } & REL3 & .793 & .082 & 19.086 & .629 \\
\hline & REL2 & .621 & .096 & 13.755 & .385 \\
\hline & REL1 & .591 & .102 & 12.873 & .349 \\
\hline & REL7 & .630 & .088 & 13.975 & .397 \\
\hline & REL6 & .594 & .091 & 13.007 & .353 \\
\hline & REL4 & .719 & .084 & 16.687 & .517 \\
\hline & REL5 & .715 & .084 & 16.566 & .512 \\
\hline \multirow{6}{*}{$\begin{array}{l}\text { Cash waqf } \\
\text { awareness }\end{array}$} & AWARE3 & .830 & .073 & 21.075 & .434 \\
\hline & AWARE2 & .837 & .078 & 21.338 & 501 \\
\hline & AWARE1 & .775 & .079 & 19.029 & .701 \\
\hline & AWARE6 & .726 & .084 & 17.357 & .527 \\
\hline & AWARE4 & .708 & .084 & 16.751 & .701 \\
\hline & AWARE5 & .658 & .074 & 15.228 & .690 \\
\hline
\end{tabular}


Table 1.

Reliability and Validity of the constructs (Continued)

\begin{tabular}{llcccc}
\hline \multicolumn{1}{c}{ Constructs } & \multicolumn{1}{c}{ Items } & $\begin{array}{c}\text { Standardized } \\
\text { regression } \\
\text { Weight }\end{array}$ & $\begin{array}{c}\text { Standard } \\
\text { error } \\
\text { (S.E) }\end{array}$ & $\begin{array}{c}\text { Critical } \\
\text { ratio } \\
\text { (C.R) }\end{array}$ & $\begin{array}{c}\text { Squared } \\
\text { multiple } \\
\text { correlation } \\
\text { (SMC) }\end{array}$ \\
\hline Attitude towards & ATTD5 & .619 & .087 & 14.017 & .384 \\
the act & ATTD6 & .811 & .073 & 20.156 & .658 \\
& ATTD7 & .728 & .082 & 17.166 & .531 \\
& ATTD3 & .738 & .081 & 17.666 & .545 \\
& ATTD4 & .334 & .102 & 6.950 & .111 \\
& ATTD2 & .813 & .077 & 20.296 & .662 \\
& ATTD1 & .533 & .092 & 11.686 & .284 \\
\hline Subjective norm & SUBNORM1 & .958 & .085 & 18.121 & .662 \\
& SUBNORM2 & .886 & .069 & 26.402 & .550 \\
& SUBNORM3 & .741 & .074 & 23.309 & .784 \\
\hline Perceived & PBC5 & .903 & .088 & 20.787 & .367 \\
behavioural ctrl & PBC6 & .800 & .088 & 18.112 & .640 \\
& PBC4 & .606 & .094 & 13.323 & .815 \\
\hline
\end{tabular}

\subsubsection{Construct reliability}

Bagozzi and Yi (1988) recommend that CR should be equal or greater than 0.60 and AVE should be equal to or greater than 0.50 . To further ensure construct validity, convergent and discriminated validity were assessed in the data with equations 1 and 2.

$$
C R=\frac{\left(\sum_{i=1}^{n} \lambda_{i}\right)^{2}}{\left(\sum_{i=1}^{n} \lambda_{i}\right)^{2}+\left(\sum_{i=1}^{n} \delta_{i}\right)^{2}}
$$

Where: $\lambda_{i}=$ The standardized loading for each observed variable $\delta_{i}=$ The error variance associated for each observed variable

Average Variance extracted from Equation 1

$$
A V E=\frac{\sum_{i=1}^{n} \lambda_{i}{ }^{2}}{n}
$$




\subsubsection{Construct Validity}

The construct validity was also evaluated. In the construct validity, the convergent and discriminant validity was used. Convergent validity is usually accomplished by demonstrating a correlation between the two measures, although it's rare that any two measures will be perfectly convergent. In the case of discriminant validity, it could show that there is no correlation at all (Carlson \& Herdman, 2012). To fulfil the construct validity value of fit indices from the standardized loadings of each item of a construct and discriminant validity, is confirmed by the correlation value between the constructs.

Based on the result of the measurement model it is confirmed, given the cut point of the fit indices the constructs awareness, religiosity, attitude towards cash waqf, subjective norms, and perceived behavioural control were valid. In the convergent validity it is found that most values of standardized loadings are statistically significant $(>0.50)$ where $p<0.001$. In the discriminant validity, results indicate that few of the estimated correlation value between the constructs were less than 0.5 .

Overall, the constructs measurement model achieved the validity requirements for constructs using the convergent validity and discriminant validity requirements for constructs. In other to conduct SEM independent constructs must be correlated with each other (Kline, 2011). The next section discusses on the structural modelling of the research.

\subsubsection{Structural Equation Modelling and Testing Mediation Effect}

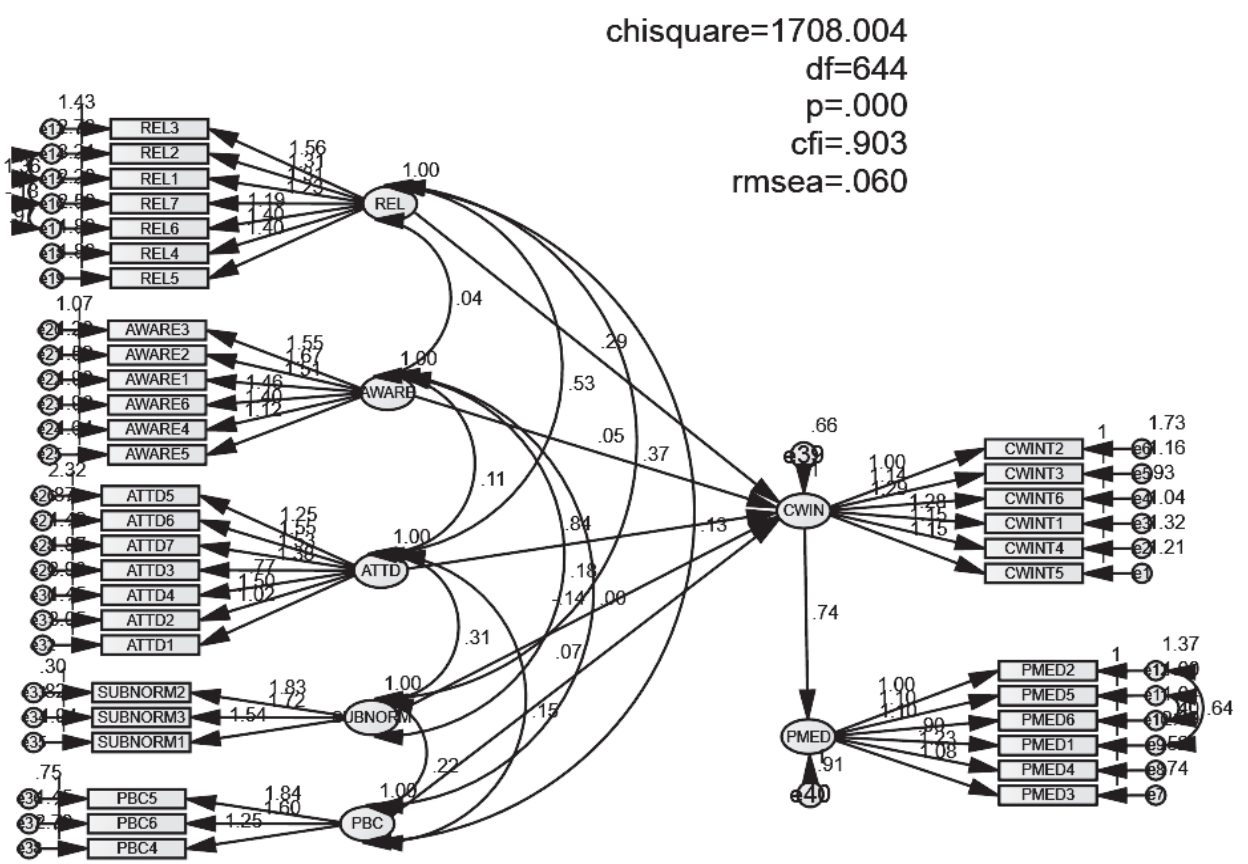

Figure 3.

SEM for constructs 
The approach to evaluate the mediating effect is bootstrapping, that is resample from a sample data. 1000 bootstrap re-sampling and 95 percent confidence intervals were performed. If Zero does not fall between the resulting confidence intervals there is a significant mediating effect. To verify the degree of the mediation (partial or full mediation), this research adopted suggestions by Mathieu and Taylor (2006). They suggest that if both the direct and indirect effect were significant, it is partial mediation. On the other hand, if the direct effect is insignificant, but the indirect effect and total effect are significant, it is noted as full mediation. In addition, the total effect denotes the extent a change in the independent construct is related to dependent construct. The direct effect is the extent in which a change in the independent construct is directly related with the dependent construct. The indirect effect is the extent to which a change in the independent construct would change the dependent construct via the mediator (cash waqf intention). The outcome of a mediator could either be partial or full mediation (Hair et al., 2010). Table 2 present the mediating effect of cash waqf intention to cash waqf awareness, religiosity, and attitude towards the act, subjective norms, and perceived behavioural control.

Table 2.

Measurement Model Estimates for Mediator

\begin{tabular}{|c|c|c|c|c|}
\hline Hypotheses & Direct Effect & $\begin{array}{l}\text { Indirect } \\
\text { Effect }\end{array}$ & Total Effect & Outcome \\
\hline$\stackrel{\text { AWARE } \longrightarrow \text { INTETION }}{\longrightarrow \text { PMED }}$ & $443^{*}$ & $.290^{*}$ & 0.733 & Partial \\
\hline 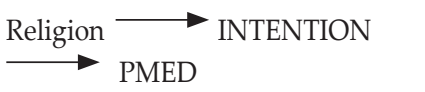 & $.103^{* *}$ & $.054^{* *}$ & 0.157 & Partial \\
\hline$\stackrel{\mathrm{ATT}}{\longrightarrow} \longrightarrow$ INTENTION & $.670^{* *}$ & $.843^{* *}$ & 1.513 & Partial \\
\hline 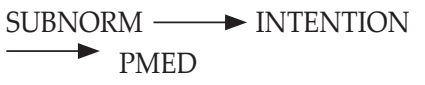 & $.204^{* *}$ & $-.144^{* *}$ & 0.06 & Partial \\
\hline $\begin{array}{l}\mathrm{PBC} \longrightarrow \text { INTENTION } \\
\longrightarrow \text { PMED }\end{array}$ & $.150^{*}$ & $0.65^{*}$ & 0.8 & Partial \\
\hline
\end{tabular}

Results of bootstrapping indicate that cash waqf intention has mediated all the relationships between the five independent constructs (cash waqf awareness, religiosity, attitude towards act, subjective norms, perceived behavioural) and dependent construct (entrepreneurship development) given the significant value of the indirect effect for all hypothesized paths. However, the degree of mediation of each construct is different. Based on Mathieu and Taylor (2006)'s advice, cash waqf intention has partially mediated all relationship between independent and dependent variables. In this case, the indirect effect of cash waqf intention in the relationship between cash waqf awareness-entrepreneurship development is 0.290 , direct effect is 0.443 at 5 percent significant level $(p<0.05)$.

Meanwhile, for religiosity, the indirect and direct effect are 0.0454 and 0.103 respectively at 1 percent significant level. The other constructs; attitude towards 
the act (cash waqf), direct effect is 0.670 , indirect effect of 0.843 (at 1 percent significant level), subjective norms have direct effect of 0.204 and indirect of -0.144 (at 1 percent significant level). Perceived behavioural control direct effect is 0.150 and an indirect effect of 0.65 , for perceived business development. Finally, the indirect and direct effect of cash waqf intention towards the relationship of Perceived behavioural and entrepreneurship development are 0.65 and 0.150 (at 5 percent significant level).

The result signifies that the effect of cash waqf intention as a mediator is very important to enhance the entrepreneurship development given that the entrepreneurs have awareness on waqf, high level of religiosity, positive attitude towards cash waqf as well as their behaviour to depend on waqf concept in order to take financing for future business development.

\section{CONCLUSION}

The research mainly focuses on cash waqf financing, to proffer it as an alternative source of financial support to micro, small and medium enterprises (MSMEs). As waqf has recently received wide coverage at international level especially the Muslim countries, it should also have been discussed in the country that have minority Muslim like Nigeria. This research thus explores the Waqf avenue to be inculcated in the cultures of Muslim Nigerian especially the small and medium entrepreneurs. Objectively, the research examines the intentions of micro entrepreneurs on cash waqf for perceived business development, explores the relationship between cash waqf awareness, religiosity, attitude towards cash waqf, subjective norms, perceived behavioural control for perceived business development, and finally investigates the mediating effect of cash waqf intention for business development. Hence, overall results of the structural model should prepare the model of entrepreneurship development in Nigeria by means of Waqf.

The research basically has tested the role of cash waqfintention as a mediator on five constructs which are cash waqf awareness, religiosity, attitude towards the act, subjective norms, and perceived behavioral control towards the entrepreneurship development The result shows that cash waqf intention have significant become a partial mediator in these five tested relationship between the independent constructs and dependent construct. Hence, it is observed that cash waqf intention is a good determinant for perceived business development in Nigeria. In addition, the two most important variables to explain the role of cash waqf intention as a mediator for business growth are cash waqf awareness and attitude towards cash waqf. It thus, implies that the entrepreneurs need to have high level of awareness and attitude towards cash waqf together with intention to succeed in their business by means of cash waqf principle.

Conclusively, this research has contributed in different aspects. First, it gives ideas to enhance the entrepreneurship development in Nigeria by introducing cash waqf as a financial source to boost the small and medium entrepreneurs. Secondly, the research confirms five constructs that can affect cash waqf intentions for perceived business development and the most significant findings are the cash waqf intention is significantly important to partially mediate the relationship of the five constructs towards entrepreneurship development. Thirdly, the research 
was able to adopt and adapt related literatures (measurement items) to resolve the limited literatures on cash waqf in the context of Nigeria and also adopted the theory of planned behaviour as a base to develop the theoretical framework of the research. In addition, references were sought from Quran to form the basis for cash waqf research and to support the theoretical framework.

However, in terms of limitation, the research sample selection was unequal in terms of respondent religion, and respondent's gender, although the data of the research was still considered for analysis purpose. Considering the research limitations, future researchers should consider improving the selection of samples for their studies. This will help in fulfilling specific needs and boost inclusion of all. On a final note, future studies may improve the current research frame work by considering and adding other relevant constructs that can affect cash waqf intentions for business development.

\section{REFERENCES}

Acs, Z. (2010). Entrepreneurship in Developing Countries. Foundations and Trends® In Entrepreneurship, 6(1), 1-68. http://doi.org/10.1561/0300000031

Adewale, A. A., Yusuf, M. B. O., Ghani, G. M., Meera, A. K. M., \& Manap, T. A. A. (2012). The Role of Institutional Trust in The Adoption of Gold Dinar in Kelantan: An Empirical Analysis. Journal of Applied Sciences, 12(20), 2148-2155. http://doi.org/10.3923/jas.2012.2148.2155

Ajzen, I. (1991). The Theory of Planned Behavior. Organizational Behavior and Human Decision Processes, 50(2), 179-211. http://doi.org/10.1016/0749-5978(91)90020-t

Ajzen, I. (2013). The Theory of Planned Behaviour. Organisational Behaviour and Human Decision Processes, 50, 179-211. http://doi.org/10.1016/j. drugalcdep.2011.10.011

Ajzen, I., Fishbein, M., Atomic, I., Agency, E., Federal, T., \& Commission, T. (1980). Theory Of Reasoned Action / Theory Of Planned Behavior. Social Psychology, 2007, 67-98. Retrieved from http://hsc.usf.edu/ kmbrown/tra_tpb.htm

Bagozzi R. P. \& Yi Youjae. (1988). “On The Evaluation of Structural Equation Models". Journal of The Academy of Marketing Science 16, pp 74-94

Baruch, Y. (2004). "Managing Careers". Pearson, Harlow.

Carlson, K. D., \& Herdman, A. O. (2012). Understanding The Impact of Convergent Validity on Research Results. Organizational Research Methods, 15(1), 17-32. http://doi.org/10.1177/1094428110392383

Creswell, J. W., \& Plano Clark, V. L. (2011). Designing and Conducting Mixed Methods Research. SAGE Publications. http://doi.org/10.1111/j.1753-6405.2007.00096.x

El-Menouar, Y. (2014). The Five Dimensions of Muslim Religiosity: Results of an Empirical Study. Methods, Data, Analyses, 8(1), 53-78.

Endsley, M. R. (1995). Toward A Theory Of Situation Awareness in Dynamic Systems. Human Factors: The Journal of The Human Factors and Ergonomics Society, 37(1), 32-64. http://doi.org/10.1518/001872095779049543

Farkas, S., \& Gubik, A. S. (2013). A Test of The Theory Of Planned Behaviour The Cross Section of The Students' Entrepreneurial Attitude in Hungary. Közgazdász Fórum, 16(115), 49-64. Retrieved from: http://search.proquest.com/ docview/1538315394?accountid=51152 
Foss, N. J., \& Klein, P. G. (2009). "Entrepreneurial Alertness and Opportunity Discovery: Origins, Attributes, Critique". Foundations.

Gibb, A.A. (2002a). "In Pursuit of A New 'Enterprise' and 'Entrepreneurship' Paradigm for Learning: Creative Destruction, New Values, New Ways Of Doing Things and New Combinations of Knowledge". International Journal of Management Reviews, 4, 3, 233-269.

Gibb, A. A. (2002b). "Creating Conducive Enviroments for Learning Entrepreneurship". Industry and Higher Education. 16(3), 135-147

Golbeck, S., \& Linetsky, V. (2013). Asset Financing With Credit Risk. Journal of Banking and Finance, 37(1), 43-59. http://doi.org/10.1016/j.jbankfin.2012.08.010

Hair, J.F., Black, W.C., Babin, B.J., Anderson, R.E. and Tatham, R.L. (2006). "Multivariate Data Analysis. Vol. 6". Pearson Prentice Hall, Upper Saddle River.

Hair, J. F., Black, W. C., Babin, B. J., \& Anderson, R. E. (2010). Multivariate Data Analysis. Vectors. http://doi.org/10.1016/j.ijpharm.2011.02.019

Hall, D.T. (2002). Careers In and Out of Organizations. SAGE, Thousand Oaks.

Hanif, M., \& Iqbal, A. M. (2010). Islamic Financing and Business Framework : A Survey. European Journal of Social Sciences, 15(4), 1-18.

Hasan, Z., \& Abdullah, M. N. (2008). The Investment of Waqf Land As An Instrument of Muslims' Economic Development in Malaysia. In The Dubai International Conference On Endowments' Investment, 4-6th February 2008 (pp. 1-25).

Hu, L., \& Bentler, P. M. (1999). Cutoff Criteria for Fit Indexes in Covariance Structure Analysis: Conventional Criteria Versus New Alternatives. Structural Equation Modeling: A Multidisciplinary Journal, 6(1), 1-55. http://doi. org/10.1080/10705519909540118

Hsu, M. H., Yen, C. H., Chiu, C. M., \& Chang, C. M. (2006). A Longitudinal Investigation of Continued Online Shopping Behavior: An Extension of The Theory of Planned Behavior. International Journal of Human-Computer Studies, 64(9), 889-904. http://doi.org/10.1016/j.ijhcs.2006.04.004

Ibrahim, H., Amir, A., \& Masron, T. A. (2013). Cash Waqf: An Innovative Instrument for Economic Development. International Review of Social Sciences and Humanities, 6, 1-7.

Ibrahim, H., Nor, E., \& Muhammad, J. (2013). Cash Waqf and Its Development in The Northern Region of Malaysia. In $4^{\text {th }}$ International Conference on Business and Economic Research (4 ${ }^{\text {th }}$ ICBER 2013) Proceeding (pp. 276-284).

Ismail Abdel Mohsin, M. (2013). Financing Through Cash-Waqf: A Revitalization to Finance Different Needs. International Journal Of Islamic and Middle Eastern Finance and Management, 6(4), 304-321. http://doi.org/10.1108/ imefm-08-2013-0094

Jaffar, M. A., \& Musa, R. (2014). Determinants of Attitude Towards Islamic Financing among Halal-Certified Micro and Smes: A Preliminary Investigation. Procedia - Social And Behavioral Sciences, 130, 135-144. http://doi.org/10.1016/j. sbspro.2014.04.017

Jiao, H., Cui, Y., Zhu, Y., \& Chen, J. (2014). Building Entrepreneurs' Innovativeness Through Knowledge Management: The Mediating Effect of Entrepreneurial Alertness. Technology Analysis \& Strategic Management, 26(5), 501-516. http:// doi.org/10.1080/09537325.2013.872774 
Kautonen, T., Van Gelderen, M., \& Tornikoski, E. T. (2013). Predicting Entrepreneurial Behaviour: A Test of The Theory of Planned Behaviour. Applied Economics, 45(August 2014), 697-707. http://doi.org/10.1080/00036846 .2011.610750

Khalid, M. (N.D.). “Waqf As A Socially Responsible Investment Instrument : A Case For Western Countries". 1-7.

Kline, R. B. (2011). Principles And Practice of Structural Equation Modeling. Structural Equation Modeling (Vol. 156). http://doi.org/10.1038/156278a0

Knabe, A. (2012). Applying Ajzen ÂA $€^{\mathrm{Tm}} S$ Theory of Planned Behavior to A Study of Online Course Adoption in Public Relations Education.

Lee, C. H., \& Rhee, B. D. (2011). Trade Credit for Supply Chain Coordination. European Journal of Operational Research. http://doi.org/10.1016/j.ejor.2011.04.004

Lee, J., \& Kwon, K. (2002). Consumers ' Use Of Credit Cards : Store Credit Card Usage As an Alternative Payment and Financing Medium. The Journal of Consumer Affairs, 36(2), 239-262. http://doi.org/10.1111/j.1745-6606.2002. tb00432.x

Malebana, J. (2014). Entrepreneurial Intentions of South African Rural University Students: A Test of The Theory of Planned Behaviour. Journal of Economics and Behavioral Studies, 6(2), 130-143.

Masyita, D., Tasrif, M., \& Telaga, A. S. (2005). A Dynamic Model For Cash Waqf Management as One of The Alternative Instruments for The Poverty Alleviation in Indonesia. In The 23rd International Conference of The System Dynamics Society Massachussets Institute of Technology (MIT) (pp. 1-29). Retrieved From: http:// www.kantakji.com/fiqh/files/wakf/b100.pdf.

Mathieu, J. E., \& Taylor S.R (2006). Clarifying Conditions and Decision Points for Mediational Type Inferences in Organizational Behavior. Journal of Organizational Behavior 27(8): 1031-1056.

Nafukho, F. M., \& Muyia, M. A. H. (2010). Entrepreneurship and Socioeconomic Development in Africa: A Reality or Myth? Journal of European Industrial Training, 34(2), 96-109. http://doi.org/10.1108/03090591011023961

National Bureau of Statistics Nigeria. (2008). Social Statistics in Nigeria, 2008. Abuja, Nigeria, 1-418. Retrieved from: http://www.efiko.org/material/ social statistics in nigeria bynbs.pdf\%5cnhttp://scholar.google.com/ scholar?hl=en\&btng=search\&q=intitle:social+statistics+in+nigeria.\#5

Nurbani, H., Yeow, J. A., Noor Ashikin, M. R., \& Chin, S. T. S. (2011). Financial Constraints and Opportunities of Micro Entreprise Entreprenuers: A Theoretical Framework. International Conference on Business and Economics Research, 1, 165-168.

Ordanini, A., Miceli, L., Pizzetti, M., \& Parasuraman, A. (2011). Crowd-Funding: Transforming Customers Into Investors through Innovative Service Platforms. Journal of Service Management. http://doi.org/10.1108/09564231111155079

Osman, M. R., \& Ali, H. (2008). Exploring Muslim Entrepreneurs' Knowledge and Usage of Islamic Financing. Seminar Keusahawanan Islam Ii Peringkat Kebangsaan, 1-26.

Schumpeter, J. A. (1934). The Theory of Economic Development. Harvard University Press. Retrieved from: http://books.google.co.uk/books?id=ozw w cogeowc\&printsec=frontcover \&dq=schumpeter+theory+econom 
ic + development\&hl=en\&ei=7q4xtjjbeyegsqauj6w2ag\&sa=x\&oi=book result\&ct=result\&resnum $=1 \&$ ved $=0$ cdaq6aewaa $\# \mathrm{v}=$ onepage $\& \mathrm{q} \& \mathrm{f}=$ true

Schumpeter, J. A. (2005). Development. Journal of Economic Literature, XLIII, 108120. http://doi.org/article

Shahimi, S., Mohd Marzuki, M. U., \& Embong, Z. (2013). Potential of Cash Waqf for Poverty Alleviation in Malaysia: A System Dynamics Approach. Jurnal Ekonomi Malaysia.

Shinsuke, N. (2014). Resuscitation of The Antique Economic System or Novel Sustainable System? Revitalization of The Traditional Islamic Economic Institutions (Waqf And Zakat) in The Postmodern Era. Kyoto Bulletin of Islamic Area Studies, 7.

Stanford, V. I., \& Brewer, E. S. (2011). Dominion or Stewardship: Understanding The Role of Religiousity in Forming Attitudes about The Environment through Pathway Analysis. In American Political Science Association Annual Conference (pp. 1-21).

Tohirin, A. (2010a). The Cash Waqf for Empowering The Small Businesses. The Tawhidi Epistemology: Zakat and Waqf Economy, 485-499.

Palamida, E., Papagiannidis, S., Xanthopoulou, D., \& Stamati, T. (2013). Predicting Entrepreneurial Team Formation Intentionality: Applying The Theory of Planned Behaviour. In $5^{\text {th }}$ Annual Euromed Conference of The Euromed Academy of Business: Building New Business Models for Success through Competitiveness and Responsibility (pp. 1241-1252).

Pallant, J. (2013).SPSS Survival Manual: A Step By Step Guide to Data Analysis Using IBM SPSS. Journal of Advanced Nursing, 3 ${ }^{\text {rd }}$, 352. http://doi.org/10.1111/17536405.12166

Pallant, J. (2010). SPSS Survival Manual: A Step By Step Guide to Data Analysis Using SPSS. Step By Step Guide to Data Analysis Using The SPSS Program. Retrieved from http://solo.bodleian.ox.ac.uk/primo_library/libweb/action/ search.do? dscnt $=1 \& v 1($ drstartday 6$)=00 \& v 1(60606418 u i 3)=a l l \_i t e m s \& s c p$. scps=scope:(ouls), scope:(net)\&tab=local\&srt=rank\&mode=advanced\&vl (1uistartwith1) $=$ contains \& $\mathrm{tb}=\mathrm{t} \& \mathrm{ind} \mathrm{x}=1 \& \mathrm{vl}($ drendyear6)=year\&vl(freet.

Parvin, L., Rahman, M. W., \& Jia, J. (2012). Determinates of Women MicroEntrepreneurship Development: An Empirical Investigation in Rural Bangladesh. International Journal of Economics and Finance, 4(5), 254-261. http:// doi.org/10.5539/ijef.v4n5p254

Petersen, M. A., \& Rajan, R. G. (1997). Trade Credit: Theories and Evidence. Review of Financial Studies, 10(3), 661-691. http://doi.org/10.1093/rfs/10.3.661

Provan, K. G., Beagles, J. E., Mercken, L., \& Leischow, S. J. (2012). Awareness of Evidence-Based Practices by Organizations in A Publicly Funded Smoking Cessation Network. Journal of Public Administration Research and Theory, 23(1), 133-153. http://doi.org/10.1093/jopart/mus011

Rai, D. (2007). Credit Rationing, Government Credit Programs and Co-Financing. Journal of Applied Economics, X(2), 361-389. Retrieved from http://www.ucema. edu.ar/publicaciones/download/volume10/rai.pdf.

Tang, J. (2009). Exploring The Constitution of Entrepreneurial Alertness: The Regulatory Focus View. Journal of Small Business E Entrepreneurship, 22(3), 221-238. http://doi.org/10.1080/08276331.2009.10593452 
Tang, J., Kacmar, K. M. M., \& Busenitz, L. (2012a). Entrepreneurial Alertness in The Pursuit of New Opportunities. Journal of Business Venturing, 27(1), 77-94. http://doi.org/10.1016/j.jbusvent.2010.07.001

Tang, J., Kacmar, K. M. M., \& Busenitz, L. (2012b). Entrepreneurial Alertness in The Pursuit of New Opportunities. Journal of Business Venturing, 27(1), 77-94. http://doi.org/10.1016/j.jbusvent.2010.07.001

Teo, T., \& Lee, C. B. (2010). Explaining The Intention to Use Technology among Student Teachers: An Application of The Theory of Planned Behavior (TPB). Campus-Wide Information Systems, 27(2), 60-67. http://doi. org/10.1108/10650741011033035

Valliere, D. (2013). Entrepreneurial Alertness and Paying Attention. Journal of Enterprising Culture, 21(1), 1-17. http://doi.org/10.1142/s0218495813500015

Von Mises, L. (1949). Human Action: A Treatise on Economics. Auburn, Al: Ludwig Von Mises Institute.

Wardiwiyono, S. (2012). Internal Control System for Islamic Micro Financing: An Exploratory Study of Baitul Maal Wat Tamwil in The City of Yogyakarta Indonesia. International Journal of Islamic and Middle Eastern Finance and Management, 5(4), 340-352. http://doi.org/10.1108/17538391211282836

Whited, T. M., \& Wu, G. (2006). Financial Constraints Risk. Review of Financial Studies, 19(2), 531-559. http://doi.org/10.1093/rfs/hhj012

Yang, X. (2011). Trade Credit Versus Bank Credit: Evidence from Corporate Inventory Financing. Quarterly Review of Economics and Finance, 51(4), 419-434. http://doi.org/10.1016/j.qref.2011.07.001 
This page is intentionally left blank 